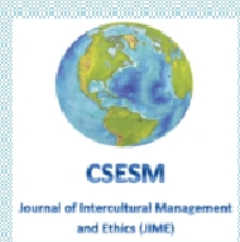

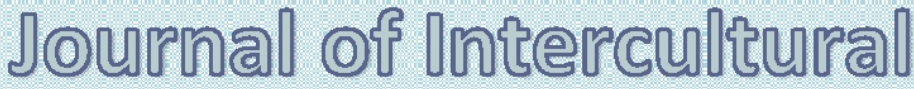

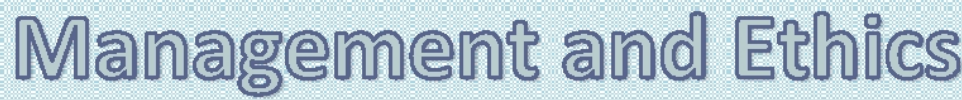

\author{
I0ME
}

ISSN 2601 - 5749, ISSN-L 2601 - 5749

Center for Socio-Economic Studies and Multiculturalism

lasi, Romania

WWW csesmioirg 


\section{TABLE OF CONTENT}

Editorial

Iulian Warter

Where Did Culture Come From? Evolutionary Foundations of Cultural Diversity

Paulo Finuras

Crash: Boeing and the Power of Culture

Thomas D. Zweifel, Vip Vyas

Political Culture, Social Polarization and Electoral Behavior. The Last Decade in Romanian

Political System

Silviu-Petru Grecu

The Principles of Transparency and Judging Others Favorably: The Talmudic View

Hershey H. Friedman, Robert B. Fireworker

Some Issues Regarding the Ethics of the Management at Romanian State-Owned

Companies .55

Baluta Aurelian Virgil, Rada Alexandru Cristian

How Does Logistics Command of the Military Navy Support Local Development and

Cultural Integration?

Rosa Caiazza

Illusion and Disillusion. Case Studies about the Constitution of a New Political Party in

Romania

Alexandru Muraru

How Could We Overcome the Feeling Of Insecurity? Explorations in the Spectrum of Polyscopic Consciousness

Anton Carpinschi

The Employees' Perceptions, Practices and Experiences Regarding the Strategic Process

Carried Out In the Public Hospitals

Ana Niculita 


\title{
SOME ISSUES REGARDING THE ETHICS OF THE MANAGEMENT AT ROMANIAN STATE-OWNED COMPANIES
}

\author{
Baluta Aurelian Virgil, PhD \\ "Spiru Haret" University, Bucharest, Romania \\ E-mail: baluta.aurelian@yahoo.com \\ Rada Alexandru Cristian \\ National Company "Posta Romana", Bucharest, Romania \\ E-mail: alexrada22@gmail.com
}

\begin{abstract}
The article includes the following sections: the importance of the ethics rules of the management at state-owned companies, including the specifics of the major topics of ethics in state-owned companies, the types of influence on the ethics of management at state-owned companies, the faith as an important reference to the ethics of the management at state-owned companies, the implications for ethics rules of the market position of state-owned companies, objectives and directions for the development of ethics rules in state-owned companies.
\end{abstract}

Keywords: management of state-owned companies, rules of ethics, the faith as reference for ethics, corporate rules of management, peculiarities of state-owned companies.

\section{Introduction}

The research is based, in addition to theoretical documentation, on a series of observations of authors resulting from their activity in state-owned companies or in the monitoring of state-owned companies in Romania.

It is justified to talk about the role of every citizen as a direct beneficiary of the ethical norms of state-owned companies. In the field of ethics applied to organizations, studies on the development of new conceptual models (Friedman \& Globerman, 2021), on ethical challenges in online research (Hanganu et al., 2021) and on the documents for management practitioners on business ethics (Austral, 2021) are important.

\section{The importance of the ethics rules of the management at state-owned companies}

Ethics has recently developed in several directions. One of the directions in which ethics has evolved is the emergence of rules and standards in certain professions. The ethics of the medical professions (medical ethics), the ethics of the military professions, the ethics of those involved in the research-development activity are well represented. The ethics of activities involving different branches, such as academic ethics, has also developed.

However, research must also be aimed at a pragmatic component that benefits society. One of the areas that generates losses in the economy is that of state-owned companies.

From a conceptual point of view, one can note the use in theory of the term "economic ethics" synonymous to "business ethics" with the meaning of the < set of rules and moral norms which refer to the conduct of agents in economic (business) activity> or the < branch of morality which synthesizes the system of values, principles and norms that have been established over time in the relations between the economic agents> (Dobrota, 1999).

There is a view in many reference books or various studies that ethics intervene in factual situations that are not covered by Regulation. For companies, including state-owned 
companies, such a finding, which is to a large extent fair, leads to the conclusion that the factual situations that ethics treat are not covered by either legal or statutory rules. The existence of formal business ethics documents in companies may, where appropriate, be either effective Regulation of business ethics by including them in their statutory law, or only commitments and declarations of intent, without the possibility of inclusion in the system of statutory rules. We propose that only those documents that provide for individualized sanctions for non-compliance should be validated as part of a company's statutory law. All the others are valuable and useful, but can only be included in the lower step of legal systematization, declarations of principles.

Ethics has reached the synthesis stage of the study object, the relevant contributions and the problems to be solved (Single, 2006). Each of the research themes of ethics is applied in the fields of management ethics in general, in the management of state-owned companies in particular.

One important issue is the holders of the rights resulting from the application of the ethics rules of management in general, of state-owned companies in particular. We believe they are entitled to invoke the application of ethics rules by managers, employees, customers, suppliers, company owners, managers of previous periods, managers who will follow, citizens in the company's area of operation, public authorities.

In the case of state-owned companies, the role of employer is played by practically all citizens. The role of public administration institutions is only to effectively exercise this quality of citizens. If a state-owned company incurs losses or does not make the full profit, it could have in the case of efficient management, all citizens will bear those costs. For this reason, it is justified to talk about the role of every citizen as a direct beneficiary of the ethical norms of state-owned companies.

From the list with beneficiaries of ethical norms, most studies focus on the relationship between managers and employees. We want further studies to deepen the other categories of beneficiaries of ethics rules in state-owned companies. It is desirable that in Romanian state-owned companies in the management-employees relationship, the issue of wage and redundancy rights should not remain dominant. Central problems in the European labour market, such as vocational training and labour flexibility, already with adequate formalization (Amodio, 2019) may have a greater weight in collective bargaining and in the ethics of the manager-employee relationship in state-owned companies.

\section{Types of influence on the ethics rules of management at state-owned companies}

State-owned companies are under Government control and the Government, in turn, is under the control of political parties. For this reason, political ethics has an important influence on the ethical norms applied by the managers of state-owned companies. Because the state plays the role of shareholder in state-owned companies, the influence of political ethics on the ethics of management of state-owned companies is of the same type and intensity as that exerted by the local culture and ethics of family companies. Thus, the evolution of ethical norms in politics will be reflected relatively quickly in the life of stateowned companies. For this reason, studies on the ethics of different political doctrines will have relevance to the prospects of the evolution of company ethics (Lind, 2015).

Ethics in other fields can be influenced by ethics in one field of activity, such as the management of state-owned companies. One of the most powerful fields, for example, is university. The inclusion in the bachelor's and master's programs of the academic ethics discipline, but also the appearance of some reference books (Gherasim, 2019) can give an example in the direction of systematizing the norms of ethics for other fields, including for state-owned companies. At the same time, the theoretical and methodological developments 
in various professions can represent an additional pressure for rigor in the management of state-owned companies.

In fact, the influence of the social environment and the family on the management and organizational culture has been highlighted for companies from different countries. The company can translate traditional ways of life into economy. In Japan, for example, the economy of enterprises, including that of state-owned companies, is guided by the family model. Solidarity specific to the family model also reaches the state economic policy in Japan, so even at the level of companies controlled by public authorities (Zărnescu, 2009).

Organizations in general, state-owned companies in particular, can be considered as entities in charge of lifelong learning. Depending on the reactions to the dynamics of the requirements of the external environment, companies, including state-owned ones, have different types of behaviour based on ethical norms. Management doctrine defines simple loop learning and double loop learning. Single-loop learning occurs when <detecting and correcting the mistakes of organizations allows it to continue to apply current policies and achieves its current objectives> and double-loop learning occurs when <the error is detected and corrected in a way that involves changing fundamental rules, policies and objectives> (Argyris, 2008). In the case of state-owned companies, large organizations with a high degree of rigidity, the simple loop learning model will be operational.

There is, of course, a strong correlation between the ethical norms of state-owned companies and those of public administration. The state is overwhelmingly present in both public administration and state-owned companies. Whether carried out directly, as in the case of public administration, or indirectly through statutory bodies (General Assembly of Shareholders, Board of Directors), state control is a common element of the two types of organizations. Under these conditions, it is natural that specific requirements of the administration regarding transparency should be transposed in the practice of some stateowned companies (Constantin, 2014). Parallels of application and good practice can also be made in the case of professional ethical norms in order to respect the rights of citizens (in the case of public administration) or consumers (in the case of state-owned companies) (Cetină, 2014). I do not believe it is an exaggeration to say that there are correlations between stateowned companies and public administration, including the implications they have on the performance of the organization, the level and profile of managerial education, as often presented by economic literature (Kiriakidis, 2011).

The ethics of the management of state-owned companies is today closely linked to the political ethics or, specifically, the ethics of the way in which the politics is made. However, this correlation is relatively recent, being visible from the moment when state-owned companies have reached a certain relevance threshold. In the middle of the twentieth century, political ethics was correlated with economic ethics but referred only to the macro-economic intervention of the state in the economy. Even when it is analysed from a practical point of view (of the concrete action in the economy), the political management (middle of twentieth century) remained relevant only for the macro-economic sphere, it did not reach the level of state-controlled companies (Novacescu, 2011).

\section{Faith as an important reference to the ethics of management at state-owned companies}

A major influence on ethics has always been the morals. Depending on the personality of the heads of state-owned companies, certain types of ethics may or may not act more strongly. In the case of managers who have maintained close ties with the church, faith-based morals can be a major factor for the ethics of management at state-owned companies. Christian morals books, for example, make an important contribution to defining ethics in its correlation with its conceptual foundations. Sometimes there is a sign of equality between ethics and morals. We thus find ethics presented as the facts of man's moral life (Saint 
Nectarius of Aegina, 2013). From the perspective of faith, the area of ethics is very wide. We find in the doctrine of the Catholic Church, themes such as: money must serve man, not govern, the danger of money idolatry or the signal that social disparities can generate violence (Pope Francis, 2018). Each of these can be reflected in the policies or statutory rules of state-owned companies. Within the same system of values, there are developments that carry forward the operational component for the economy based on moral and ethical norms derived from the sphere of faith (Bradu, 2019). In fact, all the great faiths have begun to bring their ethical considerations to the economy. In many cases, it is believed that the pages of the fundamental documents of a faith can reveal safe directions of action toward ethical wealth (Friedman, 2020).

Regardless of the country in which the state-owned company is located, there is always a combination of rules based on faith and standard secular ones. The actual relationship between faith-based and secular norms in the ethics of management of stateowned companies depends on several factors. This report is also different if we refer to formal rules or rules actually applied in practice. Among the factors that act in the dimensioning of the respective report are: the position of faith and secularism in the society, the spiritual structure of the managers of the state-owned companies, the degree of legal formalization of the ethical norms in the state companies, the structure or the degree of homogeneity of the state-owned companies, the adherence to ethical norms based on faith, the field of activity, the size of the state-owned company, the intensity of participation in the flows of the global economy.

State-owned companies may have a slight behavioural gap compared to multinationals regarding the application of ethical rules based on faith. Studies have not yet been developed to determine whether there are parameters that favour a higher share of faith-based norms in different types of companies than non-multinationals. From the empirical analyses performed by us in state-owned companies in Romania, we noticed that the structure of the university and post-university studies of the managers of state-owned companies from the point of view of the country in which they took place has a major influence. In the case of managers of state-owned companies who have been educated abroad for a long time, there is at least a partial decoupling from the ethical norms in which they were educated as children. In this type of managers, we will be able to observe a smaller weight of the involvement of the norms of ethics based on faith, until a complete secularization of the social behaviour. From the same empirical observations of us, also in the case of Romania, I noticed that the managers of state-owned companies who have been educated in the country but with relevant practice in multinational companies, keep a strong desire to preserve national specificity in everything not strictly related to professional life, so including the rules of general ethics.

There is a growing desire of the world's great religions to make known their moral and ethical norms, including to explain them. We find explanations of the relationship between the Bible and human rights or of the role of the Church in political life, valid in the doctrine of the Romanian Orthodox Church (Coman, 1997). At the same time, are available explanations of morality and virtue in Talmudic Judaism (Epstein, 2003) or of the art of transformation in the vision of Kabbalah (Berg, 2004). It is worth mentioning that Islamic ethical norms were studied and well known since the 19th century, which allowed Romania to maintain the autonomy of the Islamic community in the trial of certain disputes in the first years after the integration of Dobrogea (1878).

\section{The position of state-owned companies - implications for applicable ethics}

State-owned companies have several peculiarities that generate special requirements regarding the ethical norms of their management: the monopoly position as a bidder, the monopoly position as a buyer, larger than the average size of companies in the economy, the 
right to strategic decision on their functioning is held by administrative and political authorities, the holding of capital by the state.

The most complex implications for the management ethics of state-owned companies result from their monopoly position. The vast majority of state-owned companies have a monopoly position in the market for the goods they offer, being the only ones to offer those products or services. In many cases, they have a monopolistic position when it comes to buying certain categories of products or services. These suppliers are thus in the category of captives in relation to a state-owned company, which gives them a vulnerable position on the market.

The monopoly position of state-owned companies must not affect the overall functioning of the market. Through the current policies, strategy and actions or transactions that they employ, the management of state-owned companies must not omit one of the golden rules of the market economy: "The essence of the competitive market lies in its impersonal character. No participant may determine the terms under which other participants will have access to goods or services" (Friedman, 1995). Thus, the managers of state-owned companies will be careful not to use their power to generate artificial changes in the markets over which they have a dominant position. The impersonal character of the business decision required by the functioning of the market requires that in the transactions concluded by state-owned companies to emphasize the objective elements (price, quantity, term, commercial credit, quality, guarantees, etc.) and less the subjective aspects represented by personal relationships with business partners. If from a purely theoretical point of view the recommendation regarding the ethics of the managers of state-owned companies is quite clear, the application in practice is quite complex.

\section{The specifics of the great themes of ethics in the case of management at state-owned companies}

The doctrine and theory of ethics have identified the following major themes: how should we live? and what should we do? Each of these themes or questions of ethics has its own developments and peculiarities in management in general, in the management of stateowned companies in particular. In principle, the separation of the fields of analysis of the two themes of ethics is represented by a line that is quite easy to establish. Everything related to the professional activity at work and to achieve the objectives of the managerial position is attached to the topic <what should we do? >. Instead, everything that does not belong to the managerial position itself, including the private life of the managers of state-owned companies, falls within the theme of ethics described by the question <how should we live? $>$. Beyond this imaginary line of separation, however, there are elements of the managerial act that involve overcoming the professional framework, being at the intersection with life issues subsumed under the question <how should we live?>. In managerial practice, it is precisely these elements that may raise problems in the application of ethical rules because it is not obvious what prevails: The general living standard or the professional standard.

To the question <how should we live?>, general ethics gave an almost unanimous answer: in accordance with human nature. This simple answer can also be used in the case of ethics issues of the management at state-owned companies. However, the solution may be simple or difficult, depending on the previous exercise or social experience of the actors (managers or executives) involved. If we say that we must take into account human nature, it means that the rules of coexistence in the family and society are also applicable in the management of state-owned companies.

We consider that the requirements of the first great division of labour, that between the work of man and woman, but also of the separation between generations of attributions and hierarchy remain applicable in that component of the company's life which is not strictly 
regulated by the Job Description. In legal terms we will say that the laws of human nature are the general law. The corporate workplace rules, written in the job description, are the special law. We propose that an established rule of interpretation of the legal rules inherited from Roman law be applicable: The special law derogates from the general law, the general law does not derogate from the special law. At the same time, every situation in the life of the state-owned company must be framed by one of the rules: Corporate or general human. Here another rule of interpretation may also come from Roman law: where the law does not distinguish, nor can we distinguish, with the Latin variant ubi lex non distinguere, nec nos distingure debemus. Based on this rule, if a situation is not expressly included in the corporate rules, it will automatically be subject to general human rules.

The above considerations appear to be mere theoretical or conceptual reasoning. However, they can be a valuable milestone in the life of state-owned companies. In short, we can say that the general rules of politeness between men and women, between young and old, in other cases indicated by general or business ethics will be applicable in the relations between managers and employees, between administrators and managers, between the representatives of the majority shareholder (state) and administrators or managers.

\section{Objectives of future research on ethics in the management of state-owned companies}

One area of research is the correlation between deontology and teleology in the ethics of management of state-owned companies. The fundamental problems of good or correct, present in the general ethics, have well-defined particularities at the level of company management, with a specific emphasis on the management of state companies. It is essentially a question of the relationship between action and purpose. Deontology indicates, as a basic reference, the path and teleology has as a benchmark the purpose, the finality of the action. According to this approach, from an ethical point of view, there will be no a priori correct or a priori wrong actions of the management of state-owned companies. All actions and projects of managers at state-owned companies must thus lead to the good of the company as a whole or as a part of the state domain.

One of the objectives of the application of ethical norms by state-owned companies can be their contribution to the establishment of local, national or even international brands. Such brands will give a favourable image both to the public administration under whose authority they carry out their activity, and to the community they represent. Understood in this way, the need to have strict rules of ethics, the scope of action of state-owned companies expands. International managerial practice (Haig, 2004) has synthesized many types of brands or options for a company to go through to form a brand.

The international doctrine of management ethics can and must be applied even within state-owned companies. Respect for each employee and each business partner, ensuring conditions for mutual respect between company employees, strict compliance with procedural rules, transparency in decision-making are among the current principles of management ethics applicable even in state-owned companies. Ethics can thus become an instrument that, in the absence of rules established by law, does not harm society and the environment in which it operates (Management Study Guide, n.d.). Also, in the international doctrine of management, ethical values are sometimes defined by opposition to the unethical behaviour of organizations and employees which generate economic losses or even bankruptcy. Compliance with ethics rules is thus seen as a tool for company sustainability (Akhtar et al., 2015).

The importance of ethical norms for the management of state-owned companies can also be framed in the issue of large institutions. Modern management theory emphasizes the need for such large institutions (private or state-owned) <to maintain their autonomy and focus only on the specific functions that motivate their activity> (Drucker, 2004). In 
Romania, the applied legislation (Emergency Government Decision 109, 2010) tried to professionalize the management of state-owned companies, which can ensure their necessary autonomy. But the percentage of state-owned companies applying those rules is not overwhelming in the economy.

It is already accepted that the management practice of state-owned companies can improve through the practice of large multinational companies. Valuable practices leading to performance can be taken up in all areas of management, including business ethics. One line of action for multinational companies is the development of application codes of ethics posted on the web page. Ethical issues are thus seen as part of the company's strategy (Spătariu et al., 2015).

Economic research, as well as managerial practice, have drawn attention to the need for ethical standards in changing the managers of state-owned companies. A requirement frequently formulated by the Romanian civil society is the elimination of the radical changes that appear at any change of management in the state-owned companies. A text that has become a classic of wisdom states: "The true critic must insist more on qualities than on defects" (Addison, 2016). In the same spirit, to emphasize the positive aspects of people, Tibetan philosophy is placed within the concept of the <goodness revolution> (Goleman, 2015). There is a history within each company of the damage caused by major changes that were not dictated by objective factors but by emotional desires. Philosophical and social considerations such as those presented above, plus the statistical data of managerial errors on the occasion of the change may be the basis for consolidating a subdomain of ethics in changing the management of state-owned companies. Among the recent recommendations provided by the economic research (Coșea, 2021) is the need to prepare a document of handing over and receiving problems to be solved when changing managers or members of the Boards of Directors from state-owned companies.

In the stage of classicism, it was argued that <morality appears both naturally and artificially> and <observance of moral rules favours the public interest> (Ayer, 2009). From this perspective, although certain types of events specific to the stage of ethical noncompliance are not present in a company, avoiding the potential risk and contributing to training employees for effective social action require extensive regulations. Thus, studies that warn of the forms of ethical non-compliance present worldwide (Warter \& Warter, 2020), so potential anywhere in conditions of globalization, will be useful.

\section{Conclusions}

In the case of managers who have maintained close ties with the church, faith-based morals can be a major factor for the ethics of management at state-owned companies. Stateowned companies have several peculiarities that generate special requirements regarding the ethical norms of their management: the monopoly position as a bidder, the monopoly position as a buyer, larger than the average size of companies in the economy, the right to strategic decision on their functioning is held by administrative and political authorities, the holding of capital by the state. To the question <how should we live?>, general ethics gave an almost unanimous answer: in accordance with human nature. This simple answer can also be used in the case of ethics issues of the management at state-owned companies. All actions and projects of managers at state-owned companies must thus lead to the good of the company as a whole or as a part of the state domain.

\section{References}

Addison, J. (2016). The power of Kabbalah. Technology for the Soul. In Encyclopedia of wisdom (pp.284). Bucharest 
Akhtar, S., Arshad, M. A., Mahmood, A. \& Ahmed, A. (2015). Spiritual Quotient and Ethical Values towards Organizational Sustainability. International Letters of Social and Humanistic Sciences, 58, 1-7. 10.18052/www.scipress.com/ILSHS.58.1

Amodio, S. (2019). Like leaves in the wind. Bucharest: Editura Fundației România de Mâine.

Argyris, C. (2008). The most important 54 thinkers in management. Bucharest: Meteor Press, pp.35

Austral (2021, January 29). Etica în afaceri - Cele 8 principii de etică în business. https://www.austral.ro/blog/etica-in-afaceri-cele-8-principii-de-etica-in-business.

Ayer, A.J. (2009). Hume- a briefforword. Bucharest: All, p.98

Berg, Y. (2004). The Kabbalah Centre. New York, USA.

Bradu, P. C. (2019). Eco-human. Elements of the economic thought in the social doctrine of the Catholic Church. Bucharest: Editura Fundaţiei România de Mâine

Cetină, I., Dumitrescu, L., \& Pentescu, A. (2014) Respecting consumer rights and professional ethics- particular aspects of the romanian healthcare services. In Proceedings of the 4th International Conference on Law and Social Order (pp.129140). New York

Coman, C. (1997). The Bible in the Church. Essays on biblical topics. Bucharest: Bizantină.

Constantin, E. (2014). The principle of Transparency in administrative law. In Proceedings of the 4th International Confrence on Law and Social Order (pp.88-92). New York

Coșea, M. (2021). There is also an economy in the pandemic. Studies and articles. Bucharest: Editura Fundatiiei România de Mâine

Dobrota, N. (1999). Dictionary of Economics. Bucharest: Economica, pp.205

Drucker, P., F. (2004). Future management. Bucharest: ASAB, , pp.177

Friedman, H. (2020). Ethical Wealth Is Not a Paradox: The Talmudic Guide to Prosperity. Journal of Intercultural Management and Ethics, 4, 63-85. 10.35478/jime.2020.4.07

$\begin{array}{lll}\text { Emergency Government Decision } & \text { 109(2010). }\end{array}$ http://legislatie.just.ro/Public/DetaliiDocument/124450

Epstein, I. (2003). Judaism. Bucharest: Hasefer, pp.165-203

Friedman, H. H., \& Globerman, K. (2021). Ethics \& Consciousness in Organizations: A Conceptual Hierarchical Model. Journal of Intercultural Management and Ethics, 3, 5-24.

Friedman, M. (1995). Capitalism and freedom. Bucharest: Editura Enciclopedică, pp.139

Haig, M. (2004). Great successes of famous brands. Bucharest: Meteor Busines

Hanganu, B., Manoilescu, I.S., \& Ioan,B.G. ( 2021). Ethical challenges in online research. Journal of Intercultural Management and Ethics, 4(3), 17-24

Gherasim, Z. (2019). Ethics and academic integrity. Bucharest: Editura Fundaţiei România de Mâine.

Goleman, D. (2015). The power of good. The Dalai Lama's vision for today'

$s$ world. Bucharest: Curtea Veche, pp.59-60

Kiriakidis , P. ( 2011). Research in multidimensional education. Iași: Lumen, pp.189

Kumar, A. (2016).Business Ethics in Management. International Education and Research Journal, 2(7), 76-78

Lind,W.S. (2015). Corectitudinea politică. Bucharest: Rost

Management Study Guide (n.d.). Importance of Ethics. https://www.managementstudyguide.com/importance-of-ethics.htm

Novacescu, I. (2011). Ion I.C. Bratianu-politica conception and management. Cluj-Napoca: Eikon

Pope Francis (2018). About the world and about Europe. A philosophical perspective. ClujNapoca: Şcoala Ardeleană 
Saint Nectarius of Eghina (2013). Complete works, tome 4 Christian morality, Iasi: Doxologia, pp.93

Singer, P. (2006). Treaty on ethics. Bucharest: Polirom

Spătariu, E.C. \& Asalos, N., \& Cristina-Mihaela, G. (2008). The implications of the business ethics' aspects as constitutive part of an organization strategy in the competitive background. Amfiteatru Economic, 10, 113-118

Warter, I. \& Warter, L. (2020). Culture and tolerance in Romania. Evidence from world values survey. Journal of Intercultural Management and Ethics, 3, 87-120.

Zărnescu, N. (2009). Doctrine. Treaty on the science of minimum forecasts. Bucharest: Electra, pp.110 